\title{
Pathologic ENSAT Staging Finding v7
}

National Cancer Institute

\section{Source}

National Cancer Institute. Pathologic ENSAT Staging Finding v7. NCI Thesaurus. Code C104017.

A pathologic finding about one or more characteristics of adrenal cancer, following the rules of the ENSAT staging $v 7$ classification system. 